\title{
AraBOX and XyliBOX based catalysts for cyclopropanations, Diels-Alder cycloadditions and allylic additions
}

\author{
David Kellehan ${ }^{\text {a }}$, Fiona Kirby ${ }^{\text {a }}$, David Frain ${ }^{\text {a }}$, Antonio M. Rodríguez-García ${ }^{\mathrm{b}}$, José I. García ${ }^{\mathrm{c}}$, \\ Patrick O'Leary ${ }^{\text {a, }}$ \\ ${ }^{a}$ National University of Ireland, Galway, School of Chemistry, SMAĊT (Synthetic Methods: Asymmetric Catalytic Transformations), Ireland \\ ${ }^{\mathrm{b}}$ Departamento de Química Inorganica, Organica y Bioquimica Facultad de Ciencias Químicas, Universidad de Castilla-La Mancha, Avenida Camilo Jose Cela s/n, 13071 Ciudad \\ Real, Spain \\ ${ }^{\mathrm{c}}$ Instituto de Síntesis Química y Catálisis Homogénea, CSIC-Universidad de Zaragoza, Calle Pedro Cerbuna 12, E-50009 Zaragoza, Spain
}

\begin{abstract}
A B S T R A C T
The syntheses of three novel chiral $4,4^{\circ} \mathrm{BOX}$ ligands are described. The three ligands each have a chiral backbone and chiral sidearms, two of which are diastereomeric. These new ligands have been applied as copper complexes to asymmetric cyclopropanation reaction of styrene with ethyldiazoacetate. Enantioselectivities of up to $70 \%$ were obtained, which is the highest ee reported from the use of this ligand class in this reaction to date. The multiple stereogenic centres in the ligand resulted in a substantial additive effect and this is discussed along with interpretation of the results for previously described $4,4^{0} \mathrm{BOX}$ ligands, and a major computational study of the multiple reaction channels involved with ligands of this type. The use of complexes of $4,4^{\circ} \mathrm{BOX}$ ligands, as catalysts, in an allylic alkylation is also reported for the first time and ee's of $>70 \%$ have been achieved in this reaction. These ligands were also applied to a DielsAlder test reaction and again outperformed previous examples of this ligand type.
\end{abstract}

\section{Introduction}

Chiral 2,2'-bis(oxazoline) (BOX) ligands were first reported 20 years ago 1,2 and since this time a large number of such ligands have been reported on.3 They have been applied, as their metal complexes, to the asymmetric catalysis of a wide variety of key or- ganic reactions, such as cyclopropanations,4,5 Diels Alder cycload- ditions,6 ene reactions, 7 Mukaiyama aldol reactions8 and so on. The structure of the metal complexes has also been widely explored. Despite the success of these and other catalysts, there is still a need to develop new catalysts, which increase the toolbox available to those interested in developing asymmetric syntheses. In general, the BOX ligands reported to date are predominantly based around the same ligand backbone with variation in the pendant groups at the two available positions in the oxazoline ring or on the bridgehead carbon.

We have recently reported the first examples of 4,40 BOX ligands (Fig. 1).9-11 In these ligands, the backbone contains stereogenic centres and upon complexation with a metal, these chiral centres are internal to the metallocycle. These initial ligands have been used in the catalysis of Diels-Alder and cyclopropanation reactions with some success.

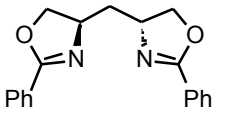<smiles>CC(C)CC1=N[C@@H](CC2COC(C(C)C)=N2)CO1</smiles><smiles>c1ccc(Pc2nc(CC3COC(c4ccccc4)=N3)co2)cc1</smiles>

(R)- PhAraBOX 1

(S)-tBuAraBOX 2

PhXyliBOX 3<smiles>CCC(C)C1=N[C@@H](C[C@@H]2COC(C(C)CC)=N2)CO1</smiles><smiles>CCC(C1=N[C@@H](C[C@@H]2COC(C(CC)c3ccccc3)=N2)CO1)c1ccccc1</smiles>

MePrXyliBOX 4

Figure 1. 4,4'-BOX ligands previously reported by this group.

The ligands are derived from two different commercially avail- able alcohols; arabitol leading to the AraBOX ligands and xylitol leading to the XyliBOX ligands which are meso unless additional chirality is incorporated into the pendant groups on the oxazoline rings (3 vs 4 and 5). 


\section{Results and discussion}

We wanted to evaluate the influence of the chirality in the backbone of the ligand on the stereoselectivity achieved by the ligand's copper complexes in the asymmetric cyclopropanation of styrene. Furthermore, we wanted to see what influence chiral pendant groups would have on the stereoselectivity. To that end we synthesized three novel 4,4 $4^{\circ} \mathrm{BOX}$ ligands 9-11 (Scheme 1).

We have previously reported on the synthesis of 12 starting from $\mathrm{D}-(+)$-arabitol; this was used as the starting point for the synthesis of ligand 11. ${ }^{9}$ The enantiomeric TBDMS protected bis-aminoalcohol 6 was prepared from L-(-)-arabitol and this was used as the starting point for the synthesis of ligands 9 and 10. In all cases, the amines were reacted with chiral acid chlorides to form amides. The acid chlorides were prepared from chiral acids and thionyl chloride and were used without purification beyond solvent removal. Amides 8 and 13 were isolated in good yield while 7 was isolated in modest $35 \%$ yield. We have developed a tandem deprotection, activation and ring closure reaction for the synthesis of our previous ligands and we again applied this methodology. Tosyl fluoride was used to deprotect the alcohols and activate them as tosylates, thus facilitating the ring closure. The DBU plays a catalytic role in the deprotection reaction but is required in excess in the cyclization step. This method allows the ligands to be prepared in excellent yields (up to 66\%) considering that the tandem DARC reactions involve 6 separate synthetic steps (three on each side).

We now had available to us three new $4,4^{\circ} \mathrm{BOX}$ ligands, and eight in total, which we then applied to the asymmetric cyclopropanation reaction of styrene with ethyl diazoacetate (Table 1). We were particularly interested in the two diastereomeric ligands 10 and 11, which would give us some insight into the relative influence of the chirality in the backbone and in the pendant groups on the stereochemical outcome of the reaction.

The reactions were conducted using $10 \mathrm{~mol} \%$ of the copper(I) triflate ligand complex relative to ethyl diazoacetate and a three fold excess of styrene. The results for ligands $1-5$ have previously been reported on but are included here for the sake of comparison

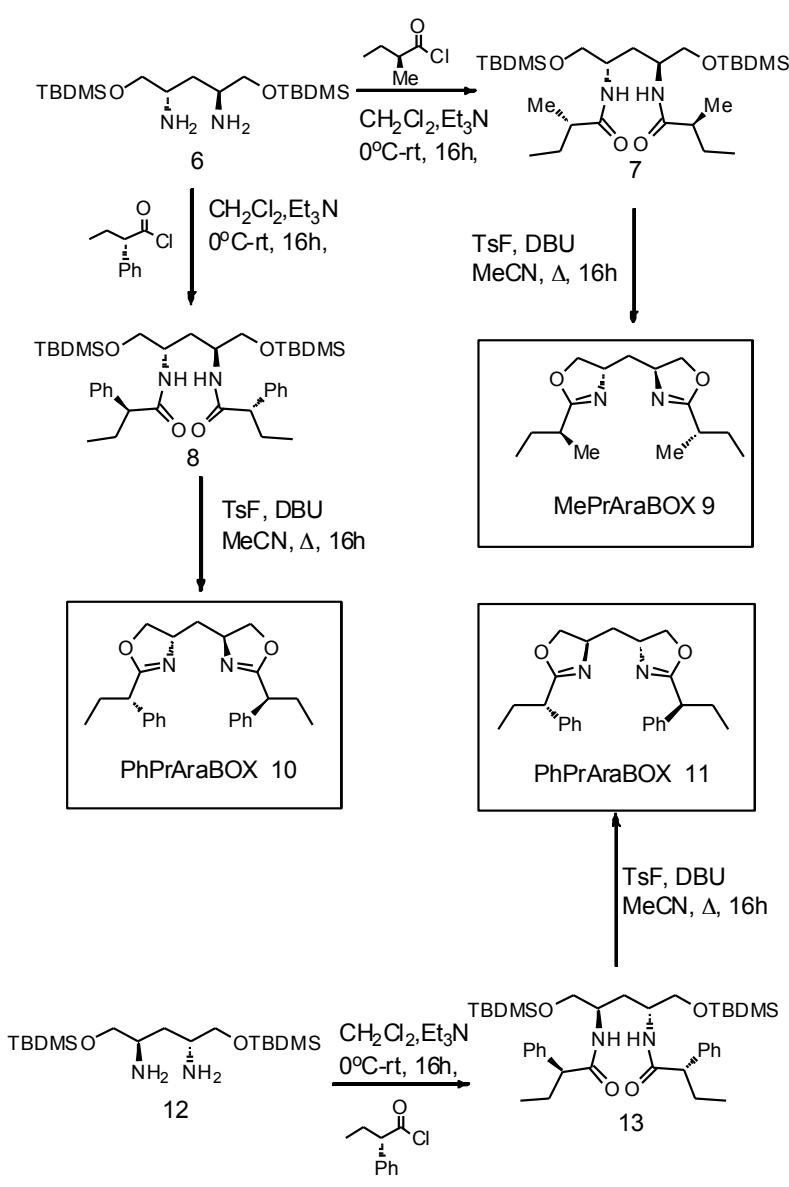

Scheme 1. Synthetic steps involved in the synthesis of ligands 9-10. 
Table 1

Ligand performance in the copper(I) catalysed asymmetric cyclopropanation reaction

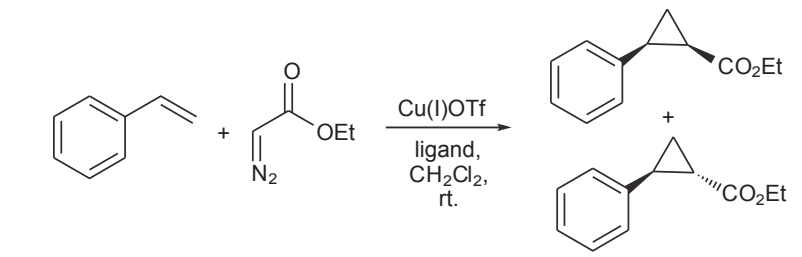

\begin{tabular}{|c|c|c|c|c|}
\hline Ligand & Conversion ${ }^{a_{\%}}$ & trans: $\operatorname{cis}^{\mathrm{a}}$ & $\%$ ee cis $^{\mathrm{b}}$ (major) & $\%$ ee $\operatorname{trans}^{\mathrm{b}}$ (major) \\
\hline 1 & 99 & $60: 40$ & $32(1 \mathrm{R}, 2 \mathrm{~S})$ & $16(1 \mathrm{R}, 2 \mathrm{R})$ \\
\hline 2 & 99 & $62: 38$ & $14(1 \mathrm{R}, 2 \mathrm{~S})$ & $7(1 \mathrm{R}, 2 \mathrm{R})$ \\
\hline 3 & 91 & $48: 52$ & - & - \\
\hline 4 & 80 & $53: 47$ & $24(1 \mathrm{~S}, 2 \mathrm{R})$ & $24(1 \mathrm{~S}, 2 \mathrm{~S})$ \\
\hline 5 & 99 & $59: 41$ & $6(1 \mathrm{~S}, 2 \mathrm{R})$ & $4(1 \mathrm{~S}, 2 \mathrm{~S})$ \\
\hline 9 & 63 & $40: 60$ & $70(1 \mathrm{~S}, 2 \mathrm{R})$ & $69(1 \mathrm{~S}, 2 \mathrm{~S})$ \\
\hline 10 & 66 & $59: 41$ & $20(1 \mathrm{R}, 2 \mathrm{~S})$ & $8(1 \mathrm{R}, 2 \mathrm{R})$ \\
\hline 11 & 67 & $37: 63$ & $64(1 \mathrm{~S}, 2 \mathrm{R})$ & $61(1 \mathrm{~S}, 2 \mathrm{~S})$ \\
\hline
\end{tabular}

as they allow us to build a picture of the stereochemical influence of each portion of the ligand.

In all cases, the ligands proved to be ineffective in influencing the diastereoselectivity of the reaction to any major degree. However, the enantioselectivities were much more encouraging.

Ligands 1 and 2 both gave low enantioselectivities, which indicated that the chiral backbone did influence the enantioselectivity of the reaction. Although these two ligands are derived from the opposite enantiomers of arabitol, they favour the same enantiomer of the product. This behaviour has previously been seen in copper $2,2^{0}$ bis(oxazoline) catalysis of Diels-Alder and ene reactions. ${ }^{12-16}$ In these cases the alteration was attributed to the change in coordination geometry around the metal when the pendant groups on the oxazoline rings were altered or when extra coordinating ligands/anions were present in the metal co-ordination sphere. This change in co-ordination geometry is often simplified as a switch between tetrahedral and square planar geometry around the metal, although the reality is thought to be someway short of these extremes.

The reaction was, as expected, not stereoselective with the meso XyliBOX ligand 3. When the chiral sidearms were added to the same backbone to give ligands 4 and 5, then modest enantioselectivities were obtained. It was apparent that the chirality in either the backbone of the ligand or in the sidearms influenced the stereoselectivity of the reaction. Ligands 9-11 were designed to combine both of these facts. The MePrAraBOX ligand 9 gave the highest enantioselectivities at $\mathrm{rv} 70 \%$ for both the cis- and trans-isomers. The PhPrAraBOX ligand 10 gave much lower enantioselectivity, even though it had been the more effective sidearm with the XyliBOX backbone. However upon closer examination we realized that the enantiomer of the cyclopropane produced in both the cis and trans case is the opposite of that seen with 9. Given that both ligands share a common backbone and the only difference is the chirality and groups on the sidearms, this gave a strong indication that we were getting a negative effect when the backbone chirality and that on the sidearm were mismatched. The PhPrAraBOX ligand 11, which is diastereomeric with 10 , gave much better results with enantioselectivities of up to $64 \%$ ee. This again gives very clear evidence of an additive effect between the stereogenic centres present in ligands 10 and 11 .

In order to gain some insight on the origin of the enantiodifferentiation leading to the enantioselectivities and absolute configurations of the major enantiomers found, we undertook a computational study, based on the previous successful results obtained with $2,2^{0}$-bisoxazolines. ${ }^{5,17-20}$
At first, we calculated the structure of the cationic 1-Cu(I)-carbene intermediate, whose optimized geometry was similar to that of the $1-\mathrm{CuCl}_{2}$ complex, determined by X-ray diffraction. ${ }^{11}$ Once the adequacy of the theoretical level used to reproduce molecular geometries was tested, we started modelling the cyclopropanation reaction using ethylene as the alkene. Although the resulting cyclopropane was not chiral, the corresponding TS of the approaches of ethylene through the Re and $\mathrm{Si}$ faces of the carbene carbon atom of the chiral bisoxazoline-copper complexes were diastereomeric, and hence different in energy. In previous studies ${ }^{5,17,18}$ we have shown that the main steric interactions responsible for the enantioselection are retained in this simplified model, leading to good estimations of the enantioselectivity of real systems, and, consequently, we adopted the same approach herein. As already mentioned, ethylene can approach the carbene carbon atom through its Re or Si faces. Furthermore, there are two conformations of the ester group for each approach. This leads to at least four possible reaction channels. Whereas the Re TS displays a chelate structure almost identical to that of the carbene intermediate, the Si TS is much more deformed, and the six-membered copper chelate ring changes its conformation from an initial half-chair to a boatlike disposition. Figure 2 highlights these structural differences by superimposing the $1-\mathrm{Cu}(\mathrm{I})$-carbene intermediate with the minimum energy Re and Si TS, respectively. However, by inspecting the relative energies of the four possible TS, one realizes that the geometric deformation observed has a rather low energy cost, since three of the four TS have almost the same energy. The modest enantioselectivity observed seems to have its origin with a slight preference of one of the reaction channels over the other three (Fig. 2). The calculated enantioselectivity [39\% ee in the (1R)-enantiomer] is in excellent agreement with the experimental values obtained (Table 1, ligand 1).

Next we considered the case of XyliBOX ligands, namely that of MePrXyliBOX 4. This situation turned out to be much more complex. First, due to the different absolute configurations at the oxazoline carbon atoms, the ligand is not $\mathrm{C} 2$-symmetric, so the number of possible alkene approaches to the corresponding carbene intermediate doubles, since we must consider the approach of the alkene through the $\mathrm{S}$ and $\mathrm{R}$ sides, both when the ester group is up and down, which are now sterically non-equivalent. Secondly, we must take into account the possible conformations not only of the six-membered chelate ring, but also of the 1-methylpropyl substituent. To this end, we carried out an exploratory conformational analysis, and we concluded that, with regard to the methylpropyl substituent, there are three main conformational dispositions gathering most of the conformational population, as shown in Figure 3. This means that if we consider again ethylene as the alkene, we have at least $(2 \times 2 \times 2 \times 3=) 24$ possible reaction channels for the reaction ( $\mathrm{Re} / \mathrm{Si}$ approaches with the ester up/down by two possible rotamers for the ester by three possible conformations for the methylpropyl substituents).

Table 2 shows the results of the calculated energies. As can be seen, the lowest energy TS corresponds to a Si approach and, overall, the (1S)-cyclopropane product is favoured. Furthermore, only the reaction channels through conformation I of the methylpropyl substituent contribute significantly in determining the enantioselectivity. Again, there is a reasonably good agreement between the calculated $[29 \%$ ee in (1S)-cyclopropane] and experimental results $[24 \%$ ee in both $(1 \mathrm{~S}, 2 \mathrm{R})$-cis- and $(1 \mathrm{~S}, 2 \mathrm{~S})$-trans-cyclopropanes). The minimum energy TS, contributing the most to the final enantioselectivity is shown in Figure 4.

Finally, we considered the analogous MePrAraBOX ligand 9. It should be noted that the only difference with ligand 4 lies in the absolute configuration of one of the carbon atoms at C-4, but this difference results in a significant asymmetric induction. Ligand 9 

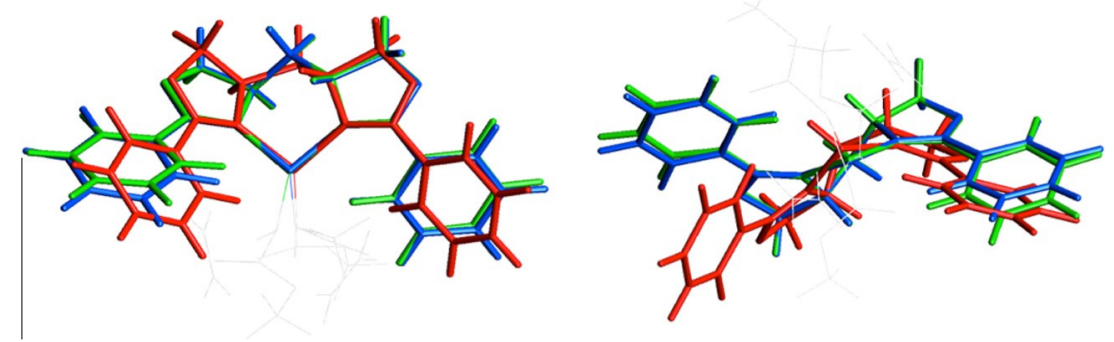

Figure 2. Superimposition of the calculated 1-Cu-carbene geometry (green) with those of the Re (blue) and Si (red) transition structures. Left, zenithal view, right, front view.
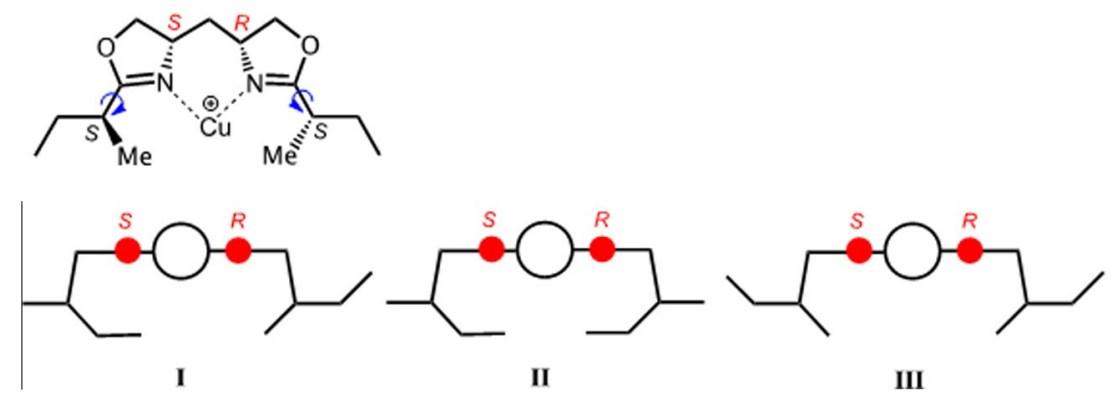

Figure 3. Most populated conformations of the methylpropyl substituents in MePrXyliBOX 4.

Table 2

Calculated enantioselectivity in the reaction of ethylene with methyl diazoacetate catalysed by the $4-$ Cu complex

\begin{tabular}{lllll}
\hline & TS & & & \\
$\mathrm{Re} / \mathrm{Si}$ & Ester up/down & MeProtam. & Ester rotam. & \\
\hline $\mathrm{Re}$ & Up & ${ }^{\text {a }}$ \\
$\mathrm{Re}$ & Down & I & 1 & 0.7 \\
$\mathrm{Re}$ & Up & I & 1 & 0.3 \\
$\mathrm{Re}$ & Down & II & 1 & 5.2 \\
$\mathrm{Re}$ & Up & III & 1 & 3.0 \\
$\mathrm{Re}$ & Down & III & 1 & 2.3 \\
$\mathrm{Re}$ & Up & I & 1 & 5.9 \\
$\mathrm{Re}$ & Down & I & 2 & 1.3 \\
$\mathrm{Re}$ & Up & II & 2 & 1.1 \\
$\mathrm{Re}$ & Down & II & 2 & 3.3 \\
$\mathrm{Re}$ & Up & III & 2 & 4.0 \\
$\mathrm{Re}$ & Down & III & 2 & 2.9 \\
$\mathrm{Si}$ & Up & I & 1 & 5.8 \\
$\mathrm{Si}$ & Down & I & 1 & 0.4 \\
$\mathrm{Si}$ & Up & II & 1 & 0.0 \\
$\mathrm{SI}$ & Down & II & 1 & 2.6 \\
$\mathrm{Si}$ & Up & III & 1 & 3.5 \\
$\mathrm{Si}$ & Down & III & 1 & 2.6 \\
$\mathrm{Si}$ & Up & I & 2 & 2.8 \\
$\mathrm{Si}$ & Down & I & 2 & 1.5 \\
$\mathrm{Si}$ & Up & II & 2 & 0.3 \\
$\mathrm{Si}$ & Down & II & 2 & 2.9 \\
$\mathrm{Si}$ & Up & III & 2 & 2.9 \\
$\mathrm{Si}$ & Down & III & 2 & 3.9 \\
\hline
\end{tabular}

${ }^{a}$ Measured in $\mathrm{kcal} \mathrm{mol}^{-1}$.

is again $\mathrm{C}_{2}$-symmetric, which reduces the number of possible reaction channels to 12 .

Table 3 shows the calculated relative energies of the corresponding TS, while the minimum energy TS contributing the most to the final enantioselectivity are shown in Figure 5. As in the case of XyliBOX, only the reaction channels through conformation I of the methylpropyl substituent contribute significantly to the reaction. However, unlike XyliBOX, the AraBOX ligand displays a clear preference for the $\mathrm{Si}$ reaction channels, leading to a calculated enantioselectivity of $75 \%$ ee in (1S)-cyclopropane, which is again

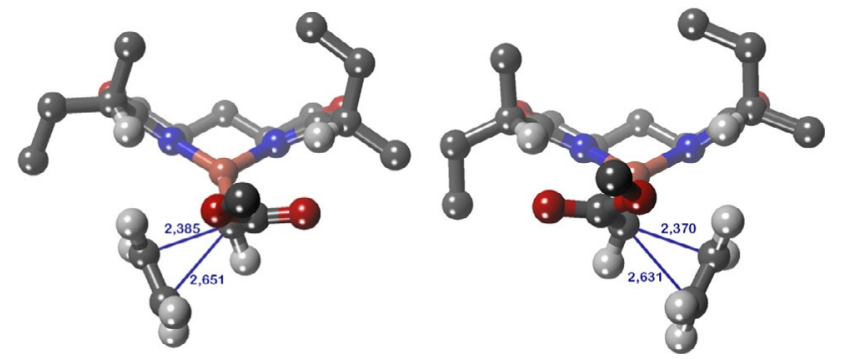

Figure 4. Minimum energy TS for the Re (left) and Si (right) alkene approaches to the 4-Cu-carbene intermediate

Table 3

Calculated enantioselectivity in the reaction of ethylene with methyl diazoacetate catalysed by the $9-\mathrm{Cu}$ complex

\begin{tabular}{|c|c|c|c|}
\hline \multicolumn{3}{|c|}{ TS } & \multirow[t]{2}{*}{$\mathrm{DDG}^{\mathrm{i}}}$, \\
\hline $\mathrm{Re} / \mathrm{Si}$ & MePr rotam. & Ester rotam. & \\
\hline $\mathrm{Re}$ & I & 1 & 1.2 \\
\hline $\mathrm{Re}$ & I & 2 & 1.8 \\
\hline $\mathrm{Re}$ & II & 1 & 2.3 \\
\hline $\mathrm{Re}$ & II & 2 & 4.3 \\
\hline $\operatorname{Re}$ & III & 1 & 4.6 \\
\hline $\operatorname{Re}$ & III & 2 & 4.0 \\
\hline $\mathrm{Si}$ & I & 1 & 0.0 \\
\hline $\mathrm{Si}$ & I & 2 & 0.5 \\
\hline $\mathrm{Si}$ & II & 1 & 4.6 \\
\hline $\mathrm{Si}$ & II & 2 & 5.0 \\
\hline $\mathrm{Si}$ & III & 1 & 2.1 \\
\hline $\mathrm{Si}$ & III & 2 & 5.7 \\
\hline
\end{tabular}

${ }^{\mathrm{a}}$ Measured in $\mathrm{kcal} \mathrm{mol}^{-1}$.

in excellent agreement with the experimental observations [ca. $70 \%$ ee in both (1S,2R)-cis- and (1S,2S)-trans-cyclopropanes]. If we compare the minimum energy TS for the Re- and Si-approaches (Fig. 5b), we can see that there are only very minor changes in the global geometry of the ligand, associated to the spatial disposition of the carbonyl group. These minor changes in the position of one 


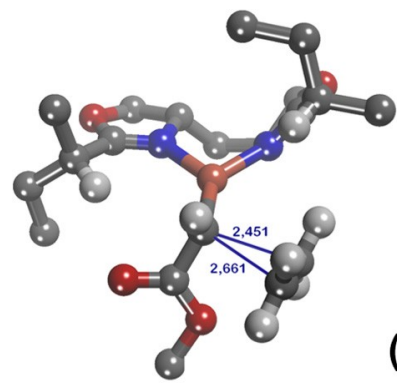

(a)
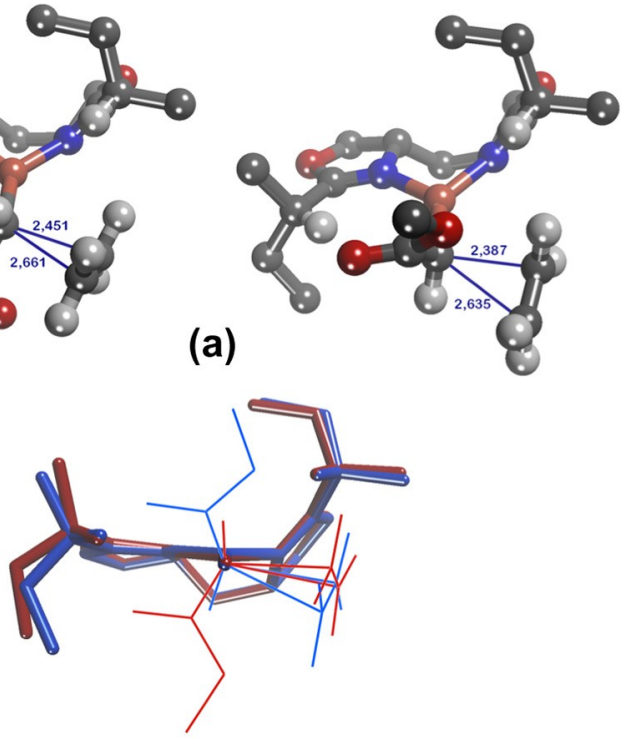

(b)

Figure 5. (a) Minimum energy TS for the Re (left) and Si (right) alkene approaches to the 9-Cu-carbene intermediate. (b) Superimposition of both TS (red, Re TS, blue, Si TS).

Table 4

Results of the allylic alkylation reaction using AraBOX ligands<smiles>CC(=O)OC(/C=C/c1ccccc1)C(=O)ON=CC(=O)C(C(C)=O)C(C)=O</smiles>

\begin{tabular}{lllll}
\hline Ligand & Time $(\mathrm{h})$, Temperature & Metal salt & Conversion $(\%)$ & $\%$ ee $(\mathrm{R}) /(\mathrm{S})$ \\
\hline 10 & 60,80 & $\mathrm{Pd}_{2}(\mathrm{dba})_{3}$ & 16 & $6(\mathrm{R})$ \\
9 & 60,80 & $\mathrm{Pd}_{2}(\mathrm{dba})_{3}$ & 99 & $72(\mathrm{R})$ \\
11 & 60,80 & $\mathrm{Pd}_{2}(\mathrm{dba})_{3}$ & 90 & $68(\mathrm{~S})$ \\
\hline
\end{tabular}

of the methylpropyl substituents seem to be in the origin of the small energy differences leading to the enantiodiscrimination.

We also applied the new ligands 9-11 to the allylic alkylation of ( \pm )-(E)-1,3-diphenyl-3-acetoxyprop-1-ene with the anion of dimethyl malonate (Table 4). We hoped that we would again see a co-operative effect between the chirality on the backbone of the ligands and that on the sidearms. The first ligand we tested was ligand 10, which had performed well in the cyclopropanation reaction. However, the reactivity was poor as was the stereoselectivity. When we applied ligands 9 and 11 to the reaction however, the reactivity was much higher and the selectivity was also improved. When ligand 9 was used, the conversion was $99 \%$ and the product was produced in $72 \%$ ee, with the (R)-enantiomer being predominant. Ligand 11 also gave good conversion and the product in $68 \%$ ee, with the (S)-enantiomer being predominant in this case. It would seem from the structures of the ligands that the backbone chirality has a substantial influence on the stereochemical outcome of the reaction, since the opposite stereochemistry on the backbone in 9 and 11 gave the opposite enantiomer of product diastereometric with the same chirality on the sidearms but opposite ligands 10 and 11 are chirality in the backbone. The interaction between the chirality in the backbone and that on the sidearms is evident from the stereoselectivity achieved with catalysts derived from these ligands from 11 leading to $68 \%$ ee (S) to 10 giving $6 \%$ ee (S).

We next applied our new ligands as their copper(II) complexes to the catalysis of Diels-Alder test reactions (Table 5). The phenylAraBOX ligand 1, which we previously reported gave the product in
Table 5

$\mathrm{Cu}(\mathrm{II}) \mathrm{AraBOX}$ complex catalysed Diels-Alder reaction

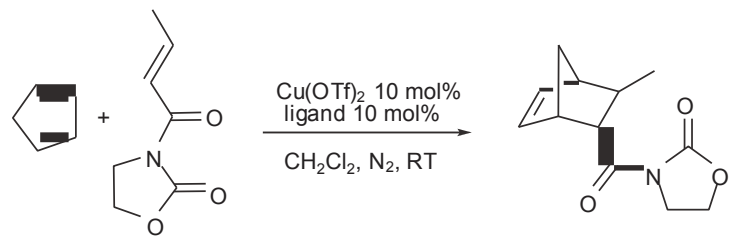

\begin{tabular}{lclr}
\hline Ligand & Conversion (\%) & endo/exo & ee endo \\
\hline 1 & 60 & $70: 30$ & $44(\mathrm{~S})$ \\
9 & 100 & $82: 18$ & $1(\mathrm{R})$ \\
10 & 97 & $70: 30$ & $45(\mathrm{R})$ \\
11 & 85 & $64: 36$ & $57(\mathrm{~S})$ \\
\hline
\end{tabular}

moderate conversion but showed diastereoselectivity (de $40 \%$ endo) and enantioselectivity (ee $44 \%$ in the endo) diastereomer. The MePrAraBOX 9 showed good diastereoselectivity but no enantioselectivity. However, the performance of ligands 10 and 11 again showed different selectivities. The complex based on ligand 10 gave good conversion and an enantioselectivity of $45 \%$ ee. The diastereomeric ligand 11 in the same reaction gave better enantioselectivity (57\%). The major enantiomer produced by the two diastereomeric ligands is different. This seems to indicate that the major control of the enantioselectivity of the reaction comes from the chirality in the backbone of the ligand. We did see a cooperative effect between the chirality on the backbone of the ligands and that on the sidearms; the ee of $57 \%$ represents the highest ee we have recorded in this reaction using the $4,4^{0} \mathrm{BOX}$ ligands.

We are currently applying these and related ligands to catalytic reactions to test their reactivity and we are also seeking to maximize the co-operative effect between various stereogenic centres.

\section{Conclusions}

We have completed the synthesis of three novel chiral $4,4^{0} \mathrm{BOX}$ ligands $9-10$. We have applied these ligands to the asymmetric copper catalysed cyclopropanation of styrene and achieved enantioselectivities of up to $70 \%$ ee. We have conducted a preliminary investigation into the factors which affect the enantioselectivity obtained when using copper complexes of these ligands. The multiple stereogenic centres in the new ligands resulted in a substantial additive effect. We are currently working on a computer based model in order to fully explore these effects and assist us in future ligand design. An additive effect was also observed in the catalysis of a Diels-Alder reaction giving the highest ee we have yet recorded with $4,4^{0} \mathrm{BOX}$ ligands in this reaction. We have also applied these ligands for the first time to the palladium catalysed allylic alkylation reaction, achieving ee's of up to $72 \%$. Our synthetic work in this area is currently ongoing particularly in the application of metal complexes of these ligands to the catalysis of different reactions.

\section{Experimental}

\subsection{General}

All other chemicals were purchased from Aldrich Chemical Company and generally used without further purification. Any necessary reagent purification, along with the drying and distillation of solvents, was carried out according to literature procedures. ${ }^{21}$ Melting points were measured on a Stuart Scientific SMP3 apparatus. IR spectra were measured on a Perkin Elmer Spectrum 1000 FT-IR, or a Perkin Elmer Spectrum One FT-IR. Optical rotations were measured on a Schmidt+Haensch L1000 polarimeter at $589 \mathrm{~nm}(\mathrm{Na})$ 
in a $10 \mathrm{~cm}$ cell. Thin layer chromatography (TLC) was carried out on precoated silica gel plates (Merck 60 F254); column chromatography was conducted using Merck silica gel 60 or Apollo Scientific silica gel 40-63 1m. Elemental analysis was performed on a Perkin Elmer 2400 analyser. ${ }^{1} \mathrm{H}$ NMR $(400 \mathrm{MHz}),{ }^{13} \mathrm{C}$ NMR $(100 \mathrm{MHz})$ were recorded on a JEOL ECX-400 NMR spectrometer. All spectra were recorded at probe temperatures (rv20 oC) using tetramethylsilane as the internal standard. All chiral liquid-liquid chromatography (HPLC) was carried out on a Varian instrument, with an UV/ Vis detector at the specified wavelength, with a Daicel CHIRALCEL OD $0.46 \mathrm{~cm} \times 25 \mathrm{~cm}$ column, using isopropanol/hexane as the solvent, under conditions described for each experiment.

\subsection{Preparation of amide 7}

Thionyl chloride $(0.27 \mathrm{ml}, 3.7 \mathrm{mmol})$ was added to a flask containing (S)-(+)-2-methylbutyric acid $(0.27 \mathrm{ml}, 2.5 \mathrm{mmol})$. The solution was heated at reflux for $3 \mathrm{~h}$ and then concentrated in vacuo. The residue was taken up in $\mathrm{CH}_{2} \mathrm{Cl}_{2}$ and concentrated once more to remove any remaining thionyl chloride. The product was then dissolved in $\mathrm{CH}_{2} \mathrm{Cl}_{2}$ and added dropwise to a solution of $6(0.4 \mathrm{~g}$, $1.1 \mathrm{mmol})$ and triethylamine $(0.34 \mathrm{ml}, 2.5 \mathrm{mmol})$ at $0 \mathrm{oC}$. This solution was left to stir for $14 \mathrm{~h}$, then warmed to room temperature. The solution was then concentrated in vacuo. Purification by column chromatography (petrol/ethyl acetate 80:20) yielded 7 $(203 \mathrm{mg}, 35 \%)$ as a colourless oil. $\mathrm{R}_{\mathrm{f}}=0.3$ (petrol/ethyl acetate 80:20); $/ \mathrm{a}]_{\mathrm{D}}^{20}{ }^{1 / 4}-15: 2\left(\mathrm{c} 0.003, \mathrm{CH}_{3} \mathrm{CN}\right) ;{ }^{1} \mathrm{H}$ NMR (400 MHz, $\mathrm{CDCl}_{3}$, $22 \mathrm{oC}$, TMS): $\mathrm{d}=6.23-6.13(\mathrm{~m}, 2 \mathrm{H} ; 2 \times \mathrm{NH}), 3.89-3.78(\mathrm{~m}, 2 \mathrm{H}$; $2 \times \mathrm{CHN}), 3.69-3.64\left(\mathrm{~m}, 4 \mathrm{H} ; 2 \times \mathrm{CH}_{2} \mathrm{OSi}\right), 2.13-2.05(\mathrm{~m}, 2 \mathrm{H}$; $\left.2 \mathrm{x} \mathrm{CHCH}_{3}\right), 1.81\left(\mathrm{t},{ }^{3} \mathrm{~J}(\mathrm{H}, \mathrm{H})=6.4 \mathrm{~Hz}, 2 \mathrm{H} ; \mathrm{CHCH}_{2} \mathrm{CH}\right), 1.69-1.56$ (m, $2 \mathrm{H}$; one of $\left.\mathrm{CH}_{2} \mathrm{CH}_{3}\right), 1.46-1.35\left(\mathrm{~m}, 2 \mathrm{H}\right.$; one of $\left.\mathrm{CH}_{2} \mathrm{CH}_{3}\right), 1.13-$ $1.09\left(\mathrm{dd}, \mathrm{J}=6.9 \mathrm{~Hz}, 3.2 \mathrm{~Hz}, 6 \mathrm{H} ; \mathrm{CH}_{3} \mathrm{CH}\right), 0.88(\mathrm{~m}, 24 \mathrm{H} ; 2 \mathrm{x} \mathrm{t}-\mathrm{Bu}$, $2 \times \mathrm{CH}_{3} \mathrm{CH}_{2}$ ), $0.05-0.04 \mathrm{ppm}$ (series of singlets due to rotamers, $\left.12 \mathrm{H} ; \mathrm{Si}\left(\mathrm{CH}_{3}\right)_{2}\right) ;{ }^{13} \mathrm{C} \mathrm{NMR}\left(100 \mathrm{MHz}, \mathrm{CDCl}_{3}, 22 \mathrm{oC}, \mathrm{TMS}\right): \mathrm{d}=176.5$ $(2 \times \mathrm{C} @ 0), 65.0 \quad\left(2 \times \mathrm{CH}_{2} \mathrm{O}\right), 48.3(2 \times \mathrm{CHN}), 43.4\left(2 \times \mathrm{CHCH}_{3}\right)$, $36.7\left(\mathrm{CHCH}_{2} \mathrm{CH}\right), 27.5\left(2 \times \mathrm{CH}_{3} \mathrm{CH}_{2}\right), 25.9\left(6 \times \mathrm{CCH}_{3}\right), 18.3(2 \times \mathrm{C})$, $17.5\left(2 \times \mathrm{CH}_{3} \mathrm{CH}\right), 12.0\left(2 \times \mathrm{CH}_{3} \mathrm{CH}_{2}\right),-5.3 \mathrm{ppm}\left(2 \times \mathrm{Si}\left(\mathrm{CH}_{3}\right)_{2}\right)$; IR (neat): $\mathrm{m}=3294,2957,2932,2862,1642 \mathrm{~cm}^{-1}$ (C@O); HRMS (ESI): $\mathrm{m} / \mathrm{z}$ calcd for $\mathrm{C}_{27} \mathrm{H}_{58} \mathrm{~N}_{2} \mathrm{O}_{4} \mathrm{Si}_{2}-\mathrm{H}^{+}: 529.3857\left[\mathrm{M}-\mathrm{H}^{+}\right]$; found: 529.3880 .

\subsection{Preparation of amide 8}

Thionyl chloride $(0.66 \mathrm{ml}, 9.12 \mathrm{mmol})$ was added to a flask containing (S)-(+)-2-phenylbutyric acid $(1.1 \mathrm{ml}, 6.1 \mathrm{mmol})$. The solution was heated at reflux for $3 \mathrm{~h}$ and then concentrated in vacuo. The residue was taken up in $\mathrm{CH}_{2} \mathrm{Cl}_{2}$ and concentrated once more to remove any remaining thionyl chloride. The product was then dissolved in $\mathrm{CH}_{2} \mathrm{Cl}_{2}$ and added dropwise to a solution of 6 (1.6 g, $2.76 \mathrm{mmol})$ and triethylamine $(1.45 \mathrm{ml}, 6.1 \mathrm{mmol})$ at $0 \mathrm{oC}$. This solution was left to stir for $14 \mathrm{~h}$, and then warmed to room temperature. The solution was then concentrated in vacuo. Purification by column chromatography (petrol/ethyl acetate 80:20) yielded 8 $(1.08 \mathrm{~g}, 60 \%)$ as a colourless oil. $\mathrm{R}_{\mathrm{f}}=0.64$ (petrol/ethyl acetate 80:20); $/ / \mathrm{a}]_{\mathrm{D}}^{20} 1 / 4-13: 6$ (c $\left.0.003, \mathrm{CH}_{3} \mathrm{CN}\right) ;{ }^{1} \mathrm{H}$ NMR (400 MHz, $\mathrm{CDCl}_{3}$, 22 oC, TMS): $\mathrm{d}=7.30-7.25(\mathrm{~m}, 10 \mathrm{H} ; \operatorname{Ar}-\mathrm{H}), 6.05\left(\mathrm{~d},{ }^{1} \mathrm{~J}(\mathrm{H}, \mathrm{H})=8.3 \mathrm{~Hz}\right.$, $2 \mathrm{H} ; 2 \times \mathrm{NH}), 3.74-3.64(\mathrm{~m}, 2 \mathrm{H} ; 2 \times \mathrm{CHN}), 3.53-3.44(\mathrm{~m}, 4 \mathrm{H}$; $\left.2 \times \mathrm{CH}_{2} \mathrm{OSi}\right), 3.21\left(\mathrm{t},{ }^{3} \mathrm{~J}(\mathrm{H}, \mathrm{H})=7.4 \mathrm{~Hz}, 2 \mathrm{H} ; 2 \times \mathrm{CHAr}\right), 2.21-2.09$ $\left(\mathrm{m}, 2 \mathrm{H}\right.$; one of $\left.\mathrm{CH}_{2} \mathrm{CH}_{3}\right), 1.84-1.73\left(\mathrm{~m}, 2 \mathrm{H}\right.$; one of $\left.\mathrm{CH}_{2} \mathrm{CH}_{3}\right), 1.64$ $\left(\mathrm{t},{ }^{3} \mathrm{~J}(\mathrm{H}, \mathrm{H})=6.4 \mathrm{~Hz}, 2 \mathrm{H} ; \mathrm{CHCH}_{2} \mathrm{CH}\right), 0.87 \quad\left(\mathrm{t},{ }^{3} \mathrm{~J}(\mathrm{H}, \mathrm{H})=7.4 \mathrm{~Hz}, 6 \mathrm{H}\right.$; $2 \times \mathrm{CH}_{3} \mathrm{CH}_{2}$ ), $0.78-0.77$ (series of singlets due to rotamers, $18 \mathrm{H}$; $2 \times \mathrm{t}-\mathrm{Bu}$ ), -0.01 to $-0.12 \mathrm{ppm}$ (series of singlets due to rotamers, $\left.12 \mathrm{H} ; \mathrm{Si}\left(\mathrm{CH}_{3}\right)_{2}\right) ;{ }^{13} \mathrm{C} \mathrm{NMR}\left(100 \mathrm{MHz}, \mathrm{CDCl}_{3}, 22 \mathrm{oC}, \mathrm{TMS}\right): \mathrm{d}=173.6$ (2x C@O), 140.2 (2 x ArCCH), 128.8 (4 x meta/ortho ArC), 128.1 ( $4 \mathrm{x}$ meta/ortho $\mathrm{ArC}), 127.2(2 \mathrm{x}$ para $\mathrm{ArC}), 64.7\left(2 \mathrm{x} \mathrm{CH}_{2} \mathrm{O}\right), 55.3$ $(2 \times \mathrm{CHAr}), 48.5(2 \times \mathrm{CHN}), 33.4\left(\mathrm{CHCH}_{2} \mathrm{CH}\right), 26.2\left(2 \mathrm{x} \mathrm{CH}_{2} \mathrm{CH}_{3}\right)$, $25.9\left(6 \times \mathrm{CCH}_{3}\right), 18.2\left(2 \times \mathrm{CCH}_{3}\right), 12.4 \quad\left(2 \times \mathrm{CH}_{3} \mathrm{CH}_{2}\right),-5.6 \mathrm{ppm}$ $\left(2 \times \mathrm{Si}\left(\mathrm{CH}_{3}\right)_{2}\right)$; IR (neat): $\mathrm{m}^{0}=3314,2957,2930,2857,1649 \mathrm{~cm}^{-1}$ (C@O); HRMS (ESI): $\mathrm{m} / \mathrm{z}$ calcd for $\mathrm{C}_{37} \mathrm{H}_{62} \mathrm{~N}_{2} \mathrm{O}_{4} \mathrm{Si}_{2}-\mathrm{H}^{+}: 653.4170$ [M- $\mathrm{H}^{+}$]; found: 653.4168 . Both ${ }^{1} \mathrm{H}$ and ${ }^{13} \mathrm{C}$ NMR showed the presence of ethyl acetate which was extremely difficult to remove completely.

\subsection{Preparation of amide 13}

Thionyl chloride $(0.83 \mathrm{~g}, 7.0 \mathrm{mmol})$ was added to a flask containing (S)-(+)-2-phenylbutyric acid $(0.77 \mathrm{~g}, 4.67 \mathrm{mmol})$. The solution was heated at reflux for $3 \mathrm{~h}$ and then concentrated in vacuo. The residue was taken up in $\mathrm{CH}_{2} \mathrm{Cl}_{2}$ and concentrated once more to remove any remaining thionyl chloride. The product was then dissolved in $\mathrm{CH}_{2} \mathrm{Cl}_{2}$ and added dropwise to a solution of 12 $(678 \mathrm{mg}, 1.87 \mathrm{mmol})$ and triethylamine $(0.57 \mathrm{ml}, 4.11 \mathrm{mmol})$ at $0 \mathrm{oC}$. This solution was left to stir for $14 \mathrm{~h}$, and then warmed to room temperature. The solution was then concentrated in vacuo. Purification by column chromatography (petrol/ethyl acetate $80: 20)$ yielded $13(910 \mathrm{mg}, 74 \%)$ as a colourless oil. $\mathrm{R}_{\mathrm{f}}=0.60$ (pet$\mathrm{rol} / \mathrm{ethyl}$ acetate 80:20); $/ \mathrm{a}]_{\mathrm{D}}^{20}{ }^{1 / 4} \mathrm{p} 18: 3\left(\mathrm{c} 0.003, \mathrm{CH}_{3} \mathrm{CN}\right) ;{ }^{1} \mathrm{H}$ NMR (400 MHz, $\mathrm{CDCl}_{3}, 22$ oC, TMS): $\mathrm{d}=7.31-7.21(\mathrm{~m}, 10 \mathrm{H} ; \mathrm{Ar}-\mathrm{H}), 6.19$ $\left(\mathrm{d},{ }^{1} \mathrm{~J}(\mathrm{H}, \mathrm{H})=7.9 \mathrm{~Hz}, 2 \mathrm{H} ; 2 \times \mathrm{NH}\right), 3.74-3.64(\mathrm{~m}, 2 \mathrm{H} ; 2 \times \mathrm{CHN})$, $3.55\left(\mathrm{~d},{ }^{1} \mathrm{~J}(\mathrm{H}, \mathrm{H})=4.6 \mathrm{~Hz}, 2 \mathrm{H}\right.$; one of $\left.\mathrm{CH}_{2} \mathrm{OSi}\right), 3.53-3.47(\mathrm{~m}, 2 \mathrm{H}$; one of $\left.\mathrm{CH}_{2} \mathrm{OSi}\right), 3.26-3.12(\mathrm{~m}, 2 \mathrm{H} ; 2 \times \mathrm{CHAr}), 2.20-2.08(\mathrm{~m}, 2 \mathrm{H}$; one of $\left.\mathrm{CH}_{2} \mathrm{CH}_{3}\right), 1.83-1.69\left(\mathrm{~m}, 2 \mathrm{H}\right.$; one of $\left.\mathrm{CH}_{2} \mathrm{CH}_{3}\right), 1.61$ (t, $\left.{ }^{3} \mathrm{~J}(\mathrm{H}, \mathrm{H})=6.0 \mathrm{~Hz}, \quad 2 \mathrm{H} ; \quad \mathrm{CHCH}_{2} \mathrm{CH}\right), \quad 0.85-0.75(\mathrm{~m}, \quad 24 \mathrm{H} ; 2 \times \mathrm{t}-\mathrm{Bu}$, $\left.2 \times \mathrm{CH}_{3} \mathrm{CH}_{2}\right), \quad 0.08-0.06 \mathrm{ppm} \quad\left(\mathrm{m}, \quad 12 \mathrm{H} ; \quad \mathrm{Si}\left(\mathrm{CH}_{3}\right)_{2}\right) ;{ }^{13} \mathrm{C} \quad \mathrm{NMR}$

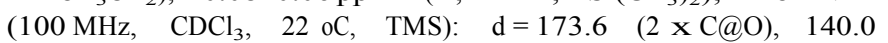
( $2 \times \mathrm{ArCCH}), 128.8$ (4 x meta/ortho ArC), 128.1 (4 x meta/ortho $\mathrm{ArC}), 127.1$ ( $2 \times$ para $\mathrm{ArC}), 64.4\left(2 \times \mathrm{CH}_{2} \mathrm{O}\right), 55.3(2 \times \mathrm{CHAr}), 48.6$ $(2 \times \mathrm{CHN}), 33.4\left(\mathrm{CHCH}_{2} \mathrm{CH}\right), 26.5\left(2 \times \mathrm{CH}_{2} \mathrm{CH}_{3}\right), 25.8\left(6 \times \mathrm{CCH}_{3}\right)$, $18.2\left(2 \times \mathrm{CCH}_{3}\right), 12.5\left(2 \times \mathrm{CH}_{3} \mathrm{CH}_{2}\right),-5.5 \mathrm{ppm}\left(2 \times \mathrm{Si}\left(\mathrm{CH}_{3}\right)_{2}\right)$; IR (neat): $\mathrm{m}=3312,2956,2929,2857,1647 \mathrm{~cm}^{-1}$ (C@O); HRMS (ESI): $\mathrm{m} / \mathrm{z}$ calcd for $\mathrm{C}_{37} \mathrm{H}_{62} \mathrm{~N}_{2} \mathrm{O}_{4} \mathrm{Si}_{2}-\mathrm{H}^{+}: 653.4170\left[\mathrm{M}-\mathrm{H}^{+}\right]$; found: 653.4175 .

\subsection{Preparation of ligand 9}

To a solution of $7(190 \mathrm{mg}, 0.36 \mathrm{mmol})$ and p-toluenesulfonyl fluoride $(138 \mathrm{mg}, 0.79 \mathrm{mmol})$ in dry acetonitrile $(10 \mathrm{ml})$ was added DBU $(118 \mathrm{1L}, 0.79 \mathrm{mmol})$. The mixture was stirred at reflux overnight, cooled and concentrated in vacuo. Purification by column chromatography (petrol/ethyl acetate 30:70) yielded 9 (52.6 mg, $55 \%$ ) as a colourless oil. $\mathrm{R}_{\mathrm{f}}=0.06$ (petrol/ethyl acetate 80:20); $1 \mathrm{a}]_{\mathrm{D}}^{20} 1 / 4 \mathrm{p} 17: 6\left(\mathrm{c} 0.003, \mathrm{CH}_{3} \mathrm{CN}\right) ;{ }^{1} \mathrm{H}$ NMR $\left(400 \mathrm{MHz}, \mathrm{CDCl}_{3}, 22 \mathrm{oC}\right.$, TMS): $\mathrm{d}=4.38-4.30\left(\mathrm{~m}, 2 \mathrm{H}\right.$; one of $\left.\mathrm{CH}_{2} \mathrm{O}\right), 4.25-4.14(\mathrm{~m}, 2 \mathrm{H}$; $2 \times \mathrm{CHN}), 3.85\left(\mathrm{t},{ }^{3} \mathrm{~J}(\mathrm{H}, \mathrm{H})=8.1 \mathrm{~Hz}, 2 \mathrm{H}\right.$; one of $\left.\mathrm{CH}_{2} \mathrm{O}\right), 2.42-2.33$ $\left(\mathrm{m}, 2 \mathrm{H} ; 2 \times \mathrm{CHCH}_{3}\right), 1.76-1.71\left(\mathrm{~m}, 2 \mathrm{H} ; \mathrm{CHCH}_{2} \mathrm{CH}\right), 1.68-1.58(\mathrm{~m}$, $2 \mathrm{H}$; one of $\left.\mathrm{CH}_{2} \mathrm{CH}_{3}\right), 1.52-1.41\left(\mathrm{~m}, 2 \mathrm{H}\right.$; one of $\left.\mathrm{CH}_{2} \mathrm{CH}_{3}\right), 1.14(\mathrm{~d}$, $\left.{ }^{1} \mathrm{~J}(\mathrm{H}, \mathrm{H})=6.9 \mathrm{~Hz}, \quad 6 \mathrm{H} ; 2 \times \mathrm{CHCH}_{3}\right), 0.90 \mathrm{ppm}\left(\mathrm{t},{ }^{3} \mathrm{~J}(\mathrm{H}, \mathrm{H})=7.3 \mathrm{~Hz}\right.$, $\left.6 \mathrm{H} ; 2 \times \mathrm{CH}_{3} \mathrm{CH}_{2}\right) ;{ }^{13} \mathrm{C}$ NMR $\left(100 \mathrm{MHz}, \mathrm{CDCl}_{3}, 22 \mathrm{oC}, \quad \mathrm{TMS}\right)$ : $\mathrm{d}=171.2 \quad(2 \times \mathrm{C} @ \mathrm{~N}), 73.1 \quad\left(2 \times \mathrm{CH}_{2} \mathrm{O}\right), \quad 64.8 \quad(2 \times \mathrm{CHN}), 47.3$ $\begin{array}{lllll}\left(\mathrm{CHCH}_{2} \mathrm{CH}\right), & 35.1 \quad\left(2 \times \mathrm{CHCH}_{3}\right), \quad 27.2 \quad\left(2 \times \mathrm{CH}_{2} \mathrm{CH}_{3}\right), & 17.4\end{array}$ $\left(2 \times \mathrm{CHCH}_{3}\right), 11.7 \mathrm{ppm}\left(\mathrm{CH}_{3} \mathrm{CH}_{2}\right)$; IR (neat): $\mathrm{m}=2971,1669 \mathrm{~cm}^{-1}$ (C@N); HRMS (ESI): $\mathrm{m} / \mathrm{z}$ calcd for $\mathrm{C}_{15} \mathrm{H}_{26} \mathrm{~N}_{2} \mathrm{O}_{2}+\mathrm{H}^{+}: 267.2072$ $\left[\mathrm{M}+\mathrm{H}^{+}\right]$; found: 262.2078 .

\subsection{Preparation of ligand 10}

To a solution of $8(1.00 \mathrm{~g}, 2.2 \mathrm{mmol})$ and p-toluenesulfonyl fluoride $(843 \mathrm{mg}, 4.84 \mathrm{mmol})$ in dry acetonitrile $(30 \mathrm{ml})$ was added DBU (724 1L, $4.84 \mathrm{mmol})$. The mixture was stirred at reflux overnight, cooled and concentrated in vacuo. Purification by column chromatography (petrol/ethyl acetate 30:70) yielded 10 $(316.8 \mathrm{mg}, 37 \%)$ as a colourless oil. $\mathrm{R}_{\mathrm{f}}=0.56$ (Petrol:ethyl acetate 
30:70); $/ \mathrm{a}]_{\mathrm{D}}^{20}{ }^{1 / 4}-18: 7\left(\mathrm{c} 0.003, \mathrm{CH}_{3} \mathrm{CN}\right) ;{ }^{1} \mathrm{H}$ NMR (400 MHz, $\mathrm{CDCl}_{3}$, $22 \mathrm{oC}$, TMS $): \mathrm{d}=7.29(\mathrm{~m}, 10 \mathrm{H} ; \mathrm{Ar}-\mathrm{H}), 4.30-4.38(\mathrm{~m}, 2 \mathrm{H}$; one of $\left.\mathrm{CH}_{2} \mathrm{O}\right), 4.19-4.27(\mathrm{~m}, 2 \mathrm{H} ; 2 \times \mathrm{CHN}), 3.82-3.88(\mathrm{~m}, 2 \mathrm{H}$; one of $\left.\mathrm{CH}_{2} \mathrm{O}\right), 3.40-3.46(\mathrm{~m}, 2 \mathrm{H} ; 2 \times \mathrm{CHAr}), 2.01-2.10(\mathrm{~m}, 2 \mathrm{H}$; one of $\left.\mathrm{CH}_{3} \mathrm{CH}_{2}\right), 1.75-1.87\left(\mathrm{~m}, 2 \mathrm{H}\right.$; one of $\left.\mathrm{CH}_{3} \mathrm{CH}_{2}\right), 1.70-1.74(\mathrm{~m}, 2 \mathrm{H}$; $\left.\mathrm{CHCH}_{2} \mathrm{CH}\right), 0.89 \mathrm{ppm}\left(\mathrm{t},{ }^{3} \mathrm{~J}(\mathrm{H}, \mathrm{H})=7.3 \mathrm{~Hz}, 6 \mathrm{H} ; 2 \times \mathrm{CH}_{3} \mathrm{CH}_{2}\right) ;{ }^{13} \mathrm{C}$ NMR $\left(100 \mathrm{MHz}, \mathrm{CDCl}_{3}, 22\right.$ oC, TMS $): \mathrm{d}=168.8(2 \mathrm{x} \mathrm{C} @ \mathrm{~N}), 140.2$ ( $2 \times \mathrm{ArCCH}), 128.6$ (4 x meta/ortho ArC), 128.0 (4 x meta/ortho $\mathrm{ArC}), 127.1(2 \times$ para $\mathrm{ArC}), 73.3\left(2 \times \mathrm{CH}_{2} \mathrm{O}\right), 64.8(2 \times \mathrm{CHN}), 47.3$ $(2 \times \mathrm{CHAr}), \quad 43.4 \quad\left(\mathrm{CHCH}_{2} \mathrm{CH}\right), \quad 27.2 \quad\left(2 \mathrm{x} \mathrm{CH}_{2} \mathrm{CH}_{3}\right), \quad 12.3 \mathrm{ppm}$ $\left(2 \mathrm{x} \mathrm{CH}_{3}\right)$; IR (neat) IR (neat): $\mathrm{m}=2964,2932,1656 \mathrm{~cm}^{-1}(\mathrm{C} @ \mathrm{~N})$; HRMS (ESI): $\mathrm{m} / \mathrm{z}$ calcd for $\mathrm{C}_{25} \mathrm{H}_{30} \mathrm{~N}_{2} \mathrm{O}_{2}-\mathrm{H}^{+}: 389.2229\left[\mathrm{M}-\mathrm{H}^{+}\right]$; found: 389.2240 .

\subsection{Preparation of ligand 11}

To a solution of $13(800 \mathrm{mg}, 1.22 \mathrm{mmol})$ and p-toluenesulfonyl fluoride $(469 \mathrm{mg}, 2.68 \mathrm{mmol})$ in dry acetonitrile $(30 \mathrm{ml})$ was added DBU (400 1L, $2.68 \mathrm{mmol})$. The mixture was stirred at reflux overnight, cooled and concentrated in vacuo. Purification by column chromatography (petrol/ethyl acetate 20:80) yielded 11 (315 mg, $66 \%$ ) as a yellow oil. $\mathrm{R}_{\mathrm{f}}=0.50$ (petrol/ethyl acetate 20:80); $\mathrm{ka}]_{\mathrm{D}}^{20} 1 / 4 \mathrm{p} 59: 8$ (c $\left.0.003, \mathrm{CH}_{3} \mathrm{CN}\right) ;{ }^{1} \mathrm{H}$ NMR $\left(400 \mathrm{MHz}, \mathrm{CDCl}_{3}, 22 \mathrm{oC}\right.$, TMS): $d=7.29(\mathrm{~m}, 10 \mathrm{H} ; \mathrm{Ar}-\mathrm{H}), 4.40-4.35\left(\mathrm{~m}, 2 \mathrm{H}\right.$; one of $\left.\mathrm{CH}_{2} \mathrm{O}\right)$, 4.28-4.17 (m, $2 \mathrm{H} ; 2 \times \mathrm{CHN}), 3.88-3.81\left(\mathrm{~m}, 2 \mathrm{H}\right.$; one of $\left.\mathrm{CH}_{2} \mathrm{O}\right)$, 3.47-3.40 (m, 2H; $2 \times \mathrm{CHAr}), 2.12-2.00\left(\mathrm{~m}, 2 \mathrm{H}\right.$; one of $\left.\mathrm{CH}_{3} \mathrm{CH}_{2}\right)$, $1.88-1.79\left(\mathrm{~m}, 2 \mathrm{H}\right.$; one of $\left.\mathrm{CH}_{3} \mathrm{CH}_{2}\right), 1.79-1.67\left(\mathrm{~m}, 2 \mathrm{H} ; \mathrm{CHCH}_{2} \mathrm{CH}\right)$, $0.88 \mathrm{ppm} \quad\left(\mathrm{t}, \quad{ }^{3} \mathrm{~J}(\mathrm{H}, \mathrm{H})=7.5 \mathrm{~Hz}, \quad 6 \mathrm{H} ; \quad 2 \times \mathrm{CH}_{3} \mathrm{CH}_{2}\right) ;{ }^{13} \mathrm{C} \quad \mathrm{NMR}$ $\left(\begin{array}{lllll}(100 \mathrm{MHz}, & \mathrm{CDCl}_{3}, & 22 \mathrm{oC}, & \mathrm{TMS}\end{array}\right): \mathrm{d}=168.7 \quad(2 \times \mathrm{C} @ \mathrm{~N}), \quad 140.1$ $(2 \times \mathrm{ArCCH}), 128.5$ (4 x meta/ortho $\mathrm{ArC}), 127.8$ (4 x meta/ortho $\mathrm{ArC}), 127.0(2 \times$ para $\mathrm{ArC}), 73.3\left(2 \times \mathrm{CH}_{2} \mathrm{O}\right), 64.6(2 \times \mathrm{CHN}), 47.2$ $(2 \times \mathrm{CHAr}), \quad 43.4 \quad\left(\mathrm{CHCH}_{2} \mathrm{CH}\right), \quad 27.0 \quad\left(2 \mathrm{x} \mathrm{CH}_{2} \mathrm{CH}_{3}\right), \quad 12.2 \mathrm{ppm}$ $\left(2 \mathrm{x} \mathrm{CH}_{3}\right)$; IR (neat): $\mathrm{m}=2964,2932,1657 \mathrm{~cm}^{-1}(\mathrm{C} @ \mathrm{~N})$; HRMS (ESI): $\mathrm{m} / \mathrm{z}$ calcd for $\mathrm{C}_{25} \mathrm{H}_{30} \mathrm{~N}_{2} \mathrm{O}_{2}-\mathrm{H}^{+}$: $389.2229\left[\mathrm{M}-\mathrm{H}^{+}\right]$; found: 389.2238 .

4.8. General procedure for asymmetric cyclopropanation catalysed by ligand-Cu(I) complexes

A solution of ligand $(0.013 \mathrm{mmol})$ and $[\mathrm{Cu}(\mathrm{OTf})]_{2} \cdot \mathrm{C}_{6} \mathrm{H}_{6}(3 \mathrm{mg}$, $0.006 \mathrm{mmol})$ in $\mathrm{CH}_{2} \mathrm{Cl}_{2}(1 \mathrm{~mL})$ was stirred under a nitrogen atmosphere at room temperature for $90 \mathrm{~min}$ and then transferred through a cotton plug to a flame-dried $\mathrm{N}_{2}$-filled Schlenk. Styrene (690 1L, $5 \mathrm{mmol}$ ) was then added. A solution of ethyldiazoacetate (137 1L, $1.2 \mathrm{mmol})$ in dry $\mathrm{CH}_{2} \mathrm{Cl}_{2}$ was added over approximately $6 \mathrm{~h}$ via a syringe pump. After the addition was complete, the reaction was stirred for an additional $12 \mathrm{~h}$. The reaction was then concentrated in vacuo to afford the crude product. The conversion and trans/cis ratio were determined by ${ }^{1} \mathrm{H}$ NMR. Flash chromatography of the residue (petrol/EtOAc; 25:1) provided a mixture of trans/cis isomers. The enantiomeric excess of each isomer was determined by chiral GC (Cyclodex-B $30 \mathrm{~m} \times 0.252 \mathrm{~mm} \times 0.251 \mathrm{~m}$ ).

\subsection{General procedure for the asymmetric allylic alkylation} reactions

Tri(benzylideneacetone)dipalladium (10 mol \%) was added to a flame dried $\mathrm{N}_{2}$ filled Schlenk. Next, the BOX ligand (15 mol \%) was weighed into a second flame dried $\mathrm{N}_{2}$ filled Schlenk and dissolved in toluene $(1 \mathrm{~mL})$. The ligand solution was then transferred under $\mathrm{N}_{2}$, into the Schlenk containing the metal. The resulting mixture was then stirred for $2 \mathrm{~h}$ at $80 \mathrm{oC}$. Next, NaH (2.2 equiv), dimethyl malonate $(2.0$ equiv) and toluene $(8 \mathrm{~mL})$, were weighed into a third flame dried $\mathrm{N}_{2}$ filled Schlenk. The resulting solution was stirred at $80 \mathrm{oC}$ for $15 \mathrm{~min}$, before the addition of $( \pm)-(\mathrm{E})-1,3-$ diphenyl-3-acetoxyprop-1-ene (1 equiv) in toluene $(1 \mathrm{~mL})$, and was stirred for a further $15 \mathrm{~min}$. The catalyst was transferred to the substrate-nucleophile mixture via a gas-tight syringe, along with a toluene rinse $(1 \mathrm{~mL})$. The reaction mixture was then stirred at $80 \mathrm{oC}$ for $60 \mathrm{~h}$. At this point, a saturated $\mathrm{NH}_{4} \mathrm{Cl}$ solution $(10 \mathrm{~mL})$ was added, the organic layer was separated and the aqueous layer was extracted with diethyl ether $(3 \times 10 \mathrm{~mL})$. The combined organic layers were washed with brine $(10 \mathrm{~mL})$, dried over anhydrous $\mathrm{Na}_{2} \mathrm{SO}_{4}$, filtered and concentrated in vacuo to yield the crude product. A ${ }^{1} \mathrm{H}$ NMR spectrum was recorded to determine the conversion [unreacted ( \pm )-(E)-1,3-diphenyl-3-acetoxyprop-1ene signal at $2.14(3 \mathrm{H})$ compared to the product signal at 4.27 $(1 \mathrm{H})$ ]. The crude product was then purified by column chromatography (pet. ether/ethyl acetate, 25:1). The enantiomeric excess (ee) of the product was then measured using chiral HPLC (CHIRACEL OD, $254 \mathrm{~nm}$, hexane (0.1\% diethylamine):iso-propyl alcohol, 98:2, $0.5 \mathrm{~mL} / \mathrm{min}), \mathrm{t}_{(\mathrm{R})} 25.2, \mathrm{t}_{(\mathrm{S})} 26.9$.

\subsection{General procedure for the Diels-Alder reaction}

To a flame-dried $\mathrm{N}_{2}$ filled Schlenk were added $\mathrm{Cu}(\mathrm{OTf})_{2}$ ( $0.033 \mathrm{mmol}, 10 \mathrm{~mol} \%)$, ligand $(0.033 \mathrm{mmol}, 10 \mathrm{~mol} \mathrm{\%}), 4 \AA$ powdered molecular sieves $(20 \mathrm{mg})$ and $\mathrm{CH}_{2} \mathrm{Cl}_{2}(2 \mathrm{~mL})$. This mixture was stirred under $\mathrm{N}_{2}$ for $90 \mathrm{~min}$ at room temperature. To this stirring catalyst was added trans-(crotonoyl)-2-oxazolidinone $(51 \mathrm{mg}$, $0.33 \mathrm{mmol})$ and freshly distilled cyclopentadiene $(0.10 \mathrm{ml}$, $1.21 \mathrm{mmol})$. The reaction proceeded at room temperature for $16 \mathrm{~h}$. A mixture of endo and exo products was isolated as an oil. The endo:exo product ratio was measured by ${ }^{1} \mathrm{H}$ NMR. The crude mixture was then purified by column chromatography (petrol/ ethyl acetate, 3:2) affording a mixture of endo and exo products as a colourless oil, from which the enantiomeric excess (ee) of the endo diastereomer was measured on the purified product using chiral HPLC (CHIRACEL OD, $254 \mathrm{~nm}$, hexane/iso-propyl alcohol, $98: 2,1.0 \mathrm{ml} / \mathrm{min}), \mathrm{t}_{(\mathrm{S})} 22.5, \mathrm{t}_{(\mathrm{R})} 28.5$.

\subsection{Computational studies}

The geometries of the reaction intermediates and transition states were optimized using density functional theory (DFT) calculations with the 6-31G(d) basis set, employing Becke's three parameterized Lee-Yang-Parr exchange functional (B3LYP), ${ }^{22,23}$ and using a GAUSSIAN 09 Programs suite. ${ }^{24}$ Frequency analyses were carried out at the same level to test the nature of the intermediates and transition structures found, according to the correct number of negative eigenvalues of the corresponding Hessian matrices, and the vibrational frequencies associated to the negative eigenvalues. In some cases, single point energy calculations were carried out using different functionals and basis sets, to check the consistency of the results. Enantioselectivities were estimated based on the calculated relative Gibbs free energies of the TS, unless otherwise stated.

\section{Acknowledgments}

This publication has emanated from research conducted with the financial support of Science Foundation Ireland (RFP/06/ CHO039).

\section{References}

1. Evans, D. A.; Woerpel, K. A.; Hinman, M. M.; Faul, M. M. J. Am. Chem. Soc. 1991,113, 726-728.

2. Corey, E. J.; Imai, N.; Zhang, H. Y. J. Am. Chem. Soc. 1991, 113, 728729.

3. Desimoni, G.; Faita, G.; Jorgensen, K. A. Chem. Rev. 2006, 106, 35613651 .

4. Carreiro, E. P.; Burke, A. J.; Ramalho, J. P. P.; Rodrigues, A. I. Tetrahedron: Asymmetry 2009, 20, 1272-1278. 
5. Garcia, J. I.; Jimenez-Oses, G.; Martinez-Merino, V.; Mayoral, J. A.; Pires, E.; Villalba, I. Chem.-A Eur. J. 2007, 13, 4064-4073.

6. Matsumoto, K.; Jitsukawa, K.; Masuda, H. Tetrahedron Lett. 2005, 46, 5687-5690.

7. Evans, D. A.; Tregay, S. W.; Burgey, C. S.; Paras, N. A.; Vojkovsky, T. J. Am. Chem. Soc. 2000, 122, 7936-7943.

8. Fabra, M. J.; Fraile, J. M.; Herrerias, C. I.; Lahoz, F. J.; Mayoral, J. A.; Perez, I. Chem. Commun. 2008, 5402-5404.

9. Frain, D.; Kirby, F.; McArdle, P.; O’Leary, P. Synlett 2009, 1261-1264.

10. Frain, D.; Kirby, F.; McArdle, P.; O’Leary, P. Tetrahedron Lett. 2010, 51, 4103-4106.

11. Kirby, F.; Frain, D.; McArdle, P.; O’Leary, P. Catal. Commun. 2010, 11, 1012-1016.

12. Thorhauge, J.; Roberson, M.; Hazell, R. G.; Jorgensen, K. A. Chem.-A Eur. J. 2002, 8, 1888-1898.

13. Bartók, M. Chem. Rev. 2010, 110, 1663-1705.

14. O’Leary, P.; Krosveld, N. P.; De Jong, K. P.; Van Koten, G.; Klein Gebbink, R. J. M. Tetrahedron Lett. 2004, 45, 3177-3180.

15. Evans, D. A.; Johnson, J. S.; Burgey, C. S.; Campos, K. R. Tetrahedron Lett. 1999, 2879.

16. McDonagh, C.; O’Leary, P. Tetrahedron Lett. 2009, 50, 979-982.

17. Fraile, J. M.; Garcia, J. I.; Martinez-Merino, V.; Mayoral, J. A.; Salvatella, L. J. Am.Chem. Soc. 2001, 123, 7616-7625.

18. Fraile, J. M.; Garcia, J. I.; Gil, M. J.; Martinez-Merino, V.; Mayoral, J. A.; Salvatella, L. Chem.-A Eur. J. 2004, 10, 758-765.

19. Fraile, José M.; García, José I.; Gissibl, A.; Mayoral, José A.; Pires, E.; Reiser, O.; Roldán, M.; Villalba, I. Chem. - pA Eur. J. 2007, 13, 88308839.

20. Garcia, J. I.; Jimenez-Oses, G.; Mayoral, J. A. Chem.-A Eur. J. 2011, 17, 529-539.

21. Armarego, W. L.; Perrin, D. D. Purification of Laboratory Chemicals, 4th ed., 1996, Elseiver

22. Becke, A. D. J. Chem. Phys. 1993, 98, 5648-5652.

23. Lee, C. T.; Yang, W. T.; Parr, R. G. Phys. Rev. B 1988, 37, 785-789.

24. Frisch, M. J.; Trucks, G. W.; Schlegel, H. B.; Scuseria, G. E.; Robb, M. A.; Cheeseman, J. R.; Scalmani, G.; Barone, V.; Mennucci, B.; Petersson, G. A.; Nakatsuji, H.; Caricato, M.; Li, X.; Hratchian, H. P.; Izmaylov, A. F.; Bloino, J.; Zheng, G.; Sonnenberg, J. L.; Hada, M.; Ehara, M.; Toyota, K.; Fukuda, R.; Hasegawa, J.; Ishida, M.; Nakajima, T.; Honda, Y.; Kitao, O.; Nakai, H.; Vreven, T.; Montgomery, J. A.; Peralta, J. E.; Ogliaro, F.; Bearpark, M.; Heyd, J. J.; Brothers, E.; Kudin, K. N.; Staroverov, V. N.; Kobayashi, R.; Normand, J.; Raghavachari, K.; Rendell, A.; Burant, J. C.; Iyengar, S. S.; Tomasi, J.; Cossi, M.; Rega, N.; Millam, J. M.; Klene, M.; Knox, J. E.; Cross, J. B.; Bakken, V.; Adamo, C.; Jaramillo, J.; Gomperts, R.; Stratmann, R. E.; Yazyev, O.; Austin, A. J.; Cammi, R.; Pomelli, C.; Ochterski, J. W.; Martin, R. L.; Morokuma, K.; Zakrzewski, V. G.; Voth, G. A.; Salvador, P.; Dannenberg, J. J.; Dapprich, S.; Daniels, A. D.; Farkas; Foresman, J. B.; Ortiz, J. V.; Cioslowski, J.; Fox, D. J. Gaussian 09, Revision A.2 and B.01; Gaussian, Inc.: Wallingford CT, 2009. 